\title{
Measles Elimination Program in Southern Khorasan-e-Razavi From 2001 to 2011
}

\author{
Hamed Ramezani-Awal-Riabi ${ }^{1}$ and Alireza Atarodi ${ }^{2,}$ \\ ${ }^{1}$ Department of Health, Gonabad University of Medical Sciences, Gonabad, Khorasan-e-Razavi, IR Iran \\ ${ }^{2}$ Department of Basic Sciences, Gonabad University of Medical Sciences, Gonabad, Khorasan-e-Razavi, IR Iran \\ *Corresponding author:Alireza Atarodi, Department of Basic Sciences, Gonabad University of Medical Sciences, Gonabad, Khorasan-e-Razavi, IR Iran. E-mail: aratarodi1387@yahoo.com
}

Received 2015 April 27; Accepted 2015 April 28.

\section{Dear Editor,}

Based on a 5-year strategy of the Eastern Mediterranean Region since 1999 in the countries that are able to eliminate measles disease, achieving high immunization coverage of over $90 \%$ with two doses of MMR, vaccine has been administered in their immunization program that the 1st dose of MMR, immunization coverage doses of vaccine had been administered in over 15 countries and at the 2 nd dose over 11 countries were covered over $95 \%$ in 2009 [1]. The elimination phase of measles will be achieved when the indigenous transmission of measles is ceased by widespread vaccination in the country. In Khorasan province (before dividing Khorasan to 3 sub-provinces of Northern, Razavi and Southern) 1920 suspected cases were reported to Center of Diseases Control of Iran (CDC) from 2001 to 2005 that suspected cases of neighboring cities of Gonabad and Bajestan cities had the same statues meaning that Ghaenat (Ghaen city) had reported 39 suspected cases from 2001 to 2006 (according to CDC), Torbat-e-Heidariah 169, Ferdows 80 and Kashmar city 79 cases, but 58 cases was reported from Gonabad city at that time. The reported cases across the country had been 122 cases from $2001-2004$ [2].

The most important index was detection of 2 suspected cases in 100,000 populations that its incidence was more than 1 and it was 22.5 and 15.4 in 2002 and 2010 in sequence. The incidence of the disease was 7.4 in Birjand, 2.6 in Bojnoord, 4.4 in Mashhad city in 2010 and 6.2 in Sabzevar city in 2007 with the most range of the disease. It seems that one of the most strong points of the program in Gonabad city was low size of its population (in comparing with other cities of Khorasan province) that makes the relationship and interaction easier with other organizations and offices resulted in fast detection and identifying of suspected cases. Considering laboratory results, we found 33 positive cases in Mashhad and 3 in Birjand city in 2010. In 2009 only 5 cases in Mashhad and 7 cases of laboratory positive cases had been recorded in Birjand city in 2007 and 2008. Reporting of detected cases of measles within 48 hours after appearing of cutaneous rashes is from the aims of measles elimination program that in this research the index has been less than $80 \%$ before the year 2007 , but after that it has increased higher than $90 \%$ through improvement of reporting system [3]. In 2006 the index was 57\% in Birjand, 75\% in Bojnoord, 54\% in Mashhad and 48\% in Sabzavar city, but it increased gradually in the following years, so that it was $71 \%$ in Birjand, $49 \%$ in Mashhad, $73 \%$ in Sabzevar and $37 \%$ (decrease) in Bojnoord city. One of the most important points in the elimination of measles program is to decrease clinically approved cases (sample less) because it decreased from national index in general that Birjand city had 1, Bojnoord 2, Mashhad 26 and Sabzevar city had 5 clinically approved cases in 2010 . We conclude that it is necessary to promote and strengthen the system of teaching, informing system and people participation in referring to health centers on time.

\section{References}

1. WHO . Manual for the laboratory diagnosis of measles and rubella virus infection. 2nd ed. 2007. pp. 35-7.

2. Zahrai SM, Dadras MN, Saboori A. National guideline for measles surveillance, elimination phase. 3 rd ed. Tehran: CDI Press; 2009.

3. Ramezani AH, Atarodi AR, Moshki M. Elemination phase of measles: An epidemiological survey in gonabad (Iran) during 20062010. Iran J Pediatr. 2012;22(2):277-8. [PubMed: 23056903] 